\title{
"Du skal ikke stikke næsen for langt frem": Et studie af normer for deltagelse og forberedelse blandt førsteårsstuderende
}

Anna Bager, ph.d.-studerende, Center for Undervisning og Laring, Business and Social Sciences, Aarhus Universitet.

Kim Jesper Herrmann, forskningsmedarbejder, Center for Undervisning og Laring, Business and Social Sciences, Aarhus Universitet.

\section{Reviewet artikel}

Studerende på videregående uddannelser forventes at deltage aktivt $i$ undervisningen og tage ansvar for egen læring. Alligevel oplever undervisere ofte, at studerende er meget tilbageholdende i timerne. Dette studie undersøger, hvilken roller normer spiller for studenteraktivitet. Tolv studerende blev interviewet to gange i løbet af et semester. Det viste sig, at normer havde en stor adfærdsregulerende rolle, ligesom det viste sig, at der var en betydelig forskel mellem udtalte og uudtalte normer. Den observation, der overraskede os mest, var, at der var meget snævre rammer for legitim deltagelse på holdtimerne, mens der var meget vide rammer for ikke-deltagelse. Disse præliminære resultater kalder på en diskussion af, hvordan normen om ansvar for egen læring fortolkes og praktiseres af universitetsstuderende.

\section{Introduktion}

På mange uddannelser suppleres ugentlige forelæsninger med hold- og øvelsestimer, hvor de studerende kan arbejde aktivt med stoffet. Her kan de studerende afprøve deres egen forståelse og, i højere grad end til forelæsningen, selv komme på banen. Derfor er der også i mange uddannelsesforløb en klar forventning om studenterdeltagelse og studenterbårne aktiviteter.

Alligevel oplever mange undervisere på mindre hold, at det kan være svært at få studerende til at deltage aktivt. Andre undervisere oplever, at to forskellige hold, der undervises med samme materiale, deltager meget forskelligt. Sådanne erfaringer er også beskrevet internationalt i et nyligt review af Rocca (2010). Det er vores påstand, at implicitte normer spiller en betydelig rolle for deltagelse, og at normer sætter faste rammer for acceptabel adfærd i holdtimesituationen. Det til trods, er der få undersøgelser af fænomenet. 


\section{Holdtimens funktion}

Holdtimer er ofte et supplement til ugentlige forelæsninger (Biggs, 2003, s. 88). Her kan de studerende afprøve og anvende deres viden og få lejlighed til at indgå i en faglig samtale med medstuderende og underviser. Et andet formål er, at de studerende gennem det selvstændige læringsarbejde bliver mere sikre i deres egen viden og forståelse og opnår en større faglig selvtillid (Anderson, 2005, s. 185). Dette håber man at opnå igennem aktiverende læringsformer og undervisning på små hold, hvor der er tid og plads til diskussion med flere deltagere. Som oftest ledes holdtimer af unge undervisere, $\mathrm{fx}$ ældre studerende med større faglig indsigt. Det forventes, at holdtimen er en bedre ramme for dybdelæring end fx forelæsningen, fordi holdtimens indretning lægger op til at udvikle, udvide og korrigere de studerendes forståelse af stoffet (Biggs, 2003).

Det afgørende for udbyttet af holdtimen er en konstruktiv og åben atmosfære, hvor de studerende føler sig trygge ved at stille spørgsmål og afprøve deres viden (Anderson, 2005). Denne atmosfære afhænger bl.a. af underviserens evne til at lade alle komme til orde og lede diskussionerne, men det afhænger i høj grad også af de normer, der blandt de studerende sættes for god holdtimekultur. Det er i flere sammenhænge vist, at normer spiller en væsentlig rolle for adfærd, også adfærd i universitetsverdenen (Hora \& Anderson, 2012; Rimal \& Real, 2003; Cialdini et al., 1990).

\section{Teori om normer}

Normer er "codes of conduct that either prescribe or proscribe behaviors that members of a group can enact" (Rimal \& Real, 2003, s. 185) og kan opdeles i to elementer: 1) hvad andre gør, kaldet deskriptive normer, og 2) hvad andre bifalder eller fordømmer, kaldet påbudte normer (Cialdini et al., 1990, s. 1015). Hvor den deskriptive norm er udtryk for, hvad man gør, er den påbudte norm udtryk for, hvad man bør eller ikke bør gøre. Normer hænger stærkt sammen med adfærd og motivation for adfærd. Opfattelsen af, at andre gør noget bestemt, legitimerer samme adfærd, dvs. gør den normal og acceptabel.

Der er ikke nødvendigvis tale om objektive regler for adfærd, og dermed kommer subjektive opfattelser til at spille en væsentlig rolle i den måde, hvorpå normerne regulerer adfærd. Normerne bliver i høj grad tolket og vurderet af den enkelte. Til trods for dette er der ofte stor enighed om normerne inden for afgrænsede fællesskaber. Med normer følger også sanktioner for adfærd, der ligger uden for normerne. Normer sætter grænserne for passende adfærd i et socialt rum, hvor brud på normer kan føre til eksklusion. De er også med til at definere et gruppetilhørsforhold og en gruppeidentitet, og bryder man med normen, kan det betyde, at man udfordrer gruppens identitet (Rimal \& Real, 2003, s. 187). 


\section{Forskningsspørgsmål}

Holdundervisning har til formål at fremme studenteraktivitet, men i praksis er dette langtfra altid tilfældet. Normteorien antyder, at adfærd i sociale fællesskaber, fx på et hold af studerende, er reguleret af normer for passende adfærd. Målet med denne analyse er at undersøge sammenhængen mellem påbudte normer og deskriptive normer ved at besvare spørgsmålet: Hvad er normerne for deltagelse i og forberedelse til holdtimer?

\section{Data og kvalitativ analysestrategi}

I forbindelse med et forskningsprojekt om deltagelse i holdtimer (Herrmann, 2013) blev 12 studerende inviteret til individuelle, semistrukturerede interview. De studerende var alle førsteårsstuderende på statskundskabsstudiet på Aarhus Universitet, og i interviewene blev de studerende bedt om at beskrive deres deltagelse i holdtimerne i faget Politisk Teori. Disse holdtimer blev afholdt hver uge, havde en varighed af to timer og var et supplement til den ugentlige forelæsning i faget. Til hver uge var der ugesedler med fire til fem arbejdsspørgsmål. Holdtimeformen på Statskundskab er baseret på studenteroplæg. I dette fag blev hvert af ugesedlens spørgsmål tildelt en læsegruppe, som havde ansvar for at forberede og holde et oplæg af 10-15 minutters varighed. Efter oplæggene var der mulighed for, at resten af holdet kunne stille spørgsmål og komme med kommentarer. De studerende indgik i faste læsegrupper, som de forventedes at have forberedt sig til inden holdtimen.

Interviewene blev transskriberet i deres fulde længde og efterfølgende behandlet i programmet Nvivo. Da projektet handlede om holdtimedeltagelse, var begrebet normer ikke eksplicit tematiseret (Kvale, 2002). Alligevel var det påfaldende, hvor ofte de studerende refererede til implicitte normer. Derfor blev passager omhandlende normer kodet selvstændigt, og det er dette materiale af et omfang på 21 sider, der danner baggrund for analysen i dette studie. Transskriberingen kan rekvireres hos forfatterne. Samtlige 12 studerende udtalte sig om normer, dog angår de tykkeste beskrivelser de deskriptive normer, mens beskrivelsen af de påbudte normer ofte var tyndere og mere implicitte.

Analysen fulgte følgende skridt: På baggrund af teorien (se ovenfor) blev de studerendes udsagn kodet deduktivt, det vil sige som værende udtryk for enten en påbudt eller en deskriptiv norm. Ydermere blev data kodet i forhold til temaerne forberedelse og deltagelse. De to typer af normer og de to temaer giver analytisk set en matrice med fire rum (se Tabel 1), og hvert af disse rum er beskrevet $\mathrm{i}$ analysen nedenfor. Endelig blev der foretaget en sammenligning (Miles \& Huberman, 2005) af henholdsvis påbudte og deskriptive normer. De anførte citater er udvalgt efter kriterier om saliens (citatet skulle udtrykke en tungvejende holdning) og repræsentativitet (holdningen, som citatet udtrykker, skulle være at finde hos mindst to andre interviewpersoner). Navnene på de studerende er pseudonymer. 


\section{Påbudte normer}

Deltagelse

Som beskrevet i teorien, er påbudte normer udtryk for, hvad man bør og ikke bør gøre, og disse normer er ofte uudtalte. Disse normer kom ofte ikke eksplicit til udtryk i interviewene. I stedet kom de påbudte normer til udtryk ved, at de studerende talte om, hvad 'man', 'nogen' eller 'folk' gør, hvad 'man' har fået at vide, eller hvad, der blev betragtet som 'selvfølgeligt'. Dette så vi blandt andet i følgende eksempler:

"... det er jo heller ikke sådan noget med at folk sidder en hel time på Facebook og ikke deltager, altså, folk deltager. Altså, dem der går her endnu, de vil gerne." (Karen).

"Det er jo det tilbagevendende problem lige siden folkeskolen (...) man fär at vide at man skal deltage mere aktivt." (Robert).

Begge citater udtrykker på hver deres måde den påbudte norm om deltagelse og en fælles forståelse af, at holdtimen - i princippet - er til for, at de studerende kan deltage i den faglige diskussion. Karen udtrykker for eksempel, at 'dem der går her' jo selvfølgelig deltager som udgangspunkt. Robert udtrykker mere eksplicit normen om aktiv deltagelse ved at bruge ordet 'skal', og, som det også fremgår af citatet, er han blevet påbudt denne norm helt siden folkeskolen. Det fremgår ikke klart af citaterne, om der udelukkende er tale om en forventning fra institutionens side eller, om normen om aktiv deltagelse rent faktisk er internaliseret af de studerende. Flere af de studerende gav udtryk for, at holdtimen ikke kan fungere uden deltagelse fra de studerende, hvilket tyder på, at den påbudte norm om aktiv deltagelse til en vis grad er delt. Modsat tyder Roberts udsagn på, at den påbudte norm ikke er internaliseret.

\section{Forberedelse}

Som ovenfor beskrevet kom de påbudte normer om forberedelse ofte kun implicit til udtryk. Flere studerende gav udtryk for, at 'nogle' i det mindste var nødt til at forberede sig. Blandt andet anså de studerende det som uacceptabelt at være uforberedt til et oplæg.

"... det duer selvfølgelig ikke i den store sammenhæng, hois alle ikke har forberedt sig." (Klaudia).

"... selvfølgelig er det ikke så accepteret, hvis man ikke har lavet [forberedt] et oplæg." (Jan).

Alle interviewpersoner gav udtryk for, at oplægsgrupperne 'selvfølgeligt' bør forberede sig, da det blev opfattet som en forudsætning for, at holdtimen - sådan som den var organiseret her - kunne lykkes. Ligeledes syntes de studerende at dele en forståelse af, at 'studerende' bør være forberedt. Denne påbudte norm kom for eksempel tydeligt frem i Klaudias udsagn om, at holdtimen ikke kan fungere, hvis ingen har forberedt sig. 


\section{Deskriptive normer}

Hvor påbudte normer udtrykker det, man bør gøre, er deskriptive normer karakteriseret ved det, de studerende rent faktisk gør. I interviewene kunne dette ses i de studerendes skelnen mellem hvad 'man' gør, og hvad 'jeg' gjorde.

\section{Deltagelse}

Når de studerende fortalte om deres deltagelse i diskussioner på holdtimen, talte de meget ofte om at bidrage med noget 'relevant'. Ikke at 'sige noget bare for at sige noget'. Hvad der blev oplevet som relevant, var der forskellige tolkninger af. Der syntes at være bred enighed om, at det var uacceptabelt at deltage for at promovere sig selv eller for at give sine personlige politiske holdninger til kende. Nogle studerende syntes at kunne tolerere perifere udsagn så længe, de havde relation til dagens emne. Andre vurderede relevans mere snævert, hvilket kommer til udtryk i følgende citat:

"Der kører det bare tit ud af en tangent (IW: okay), fordi der er nogen $i$ klassen der synes, mere end jeg, at det er sjovt (IW: ja) at diskutere ting som ingen rele.../ i hvert fald på ingen måde er relevant over for eksamen (IW: ja). Så kan man jo så diskutere om det er relevant over for...virkeligheden." (Robert).

Roberts kategoriske skelnen mellem eksamen og virkelighed er prægnant men går igen i mange studerendes udsagn. For disse studerende var det afgørende, at den sparsomme tid på holdtimen blev brugt på eksamensrelevante spørgsmål og bidrag. Mange af disse studerende udtrykte irritation og frustration over bidrag til diskussionen, som ikke direkte kunne relateres til eksamen.

I relation til dette fortæller mange studerende om, at de bevidst overvejer om de skal sige noget, og at andres reaktion betyder noget for, hvad de gør.

"Jeg er lidt bange for at være for ærlig eller komme til at sige et eller andet, som nogen ville rynke på næsen af [...] det ved jeg da godt er fjollet, men ja, jeg tror da den ligger meget ved mig, at jeg ikke deltager." (Michael).

"Vi har én fyr, der kommer LIGE fra gymnasiet [...] jeg tror bare folk sidder sådan: 'Eeej, det er lidt for meget' og sådan holdninger. 'Du skal ikke stikke næsen for langt frem' [...] jeg er ikke sådan selv bange for at sige noget dumt, men jeg tror det er dét, der afholder mange fra at [deltage]." (Margrethe).

Citaterne fra Michael og Margrethe - og mange andre studerende - udtrykker en udbredt bekymring for, hvad de andre studerende tænker om én. Blandt andet ville de studerende meget nødigt betragtes som gymnasieagtige eller som nogen, der stikker næsen for langt frem. For Michael havde det den konsekvens, at han ikke deltog i diskussionerne, mens Margrethe valgte at deltage - dog med en meget stærk bevidsthed om normerne. 
I læsningen af interviewmaterialet var det overraskende, at der ikke kun var normer for deltagelse men også normer for ikke-deltagelse, om end normerne for ikkedeltagelse havde en helt anden karakter. Helt generelt kom det til udtryk, at ikkedeltagelse var helt accepteret. Så længe vedkommende ikke forstyrrede de andre, blev det anset for ukontroversielt, hvis nogen bevidst valgte ikke at bidrage til undervisningen. Dette kom blandt andet til udtryk i følgende citater:

"Jeg synes heller ikke, at det er en, øh ... pligt for folk at deltage [...] hois man gerne vil deltage, så er man fri til at deltage, og så skal der nok være andre, der også godt vil deltage." (Michael).

"Jeg vil også have lov til, hvis jeg en eller anden dag bare er helt vildt træt og af en eller anden grund er taget til holdtime alligevel (IW: ja), så vil jeg også have lov til ikke at høre efter. Det er jo min egen ret." (Karen).

I Michaels udsagn ser vi, at friheden til at deltage i timen bliver tolket som en frihed til ikke at deltage. Hvad der også er interessant ved udsagnet er, at friheden til ikke at deltage retfærdiggøres med, at nogle nok skal deltage. Karens udsagn sætter denne frihed på spidsen ved at betragte det som en personlig ret ikke at deltage.

\section{Forberedelse}

Der var altså vide grænser for ikke-deltagelse, og på samme måder gav interviewene indtryk af stor tolerance for manglende eller sparsom forberedelse. Direkte adspurgt svarede samtlige tolv studerende, at det var acceptabelt ikke at være forberedt.

"(Interviewer: Ville det for eksempel være i orden, at man kom i en tremandsgruppe og sagde: 'Ved I hvad, jeg har simpelt hen ikke faet læst'?) [...] Ja, det ville da være fint nok. Det synes jeg, ja ... sådan ER det jo nogle gange". (Klaudia).

Der var dog én vigtig undtagelse: Studerende med ansvar for oplæg forventedes at være velforberedte.

"Hvis man ligesom ved, at der er nogen, der laver opleg $i$ det her, så har man ikke nær så høj grad et ansvar for at være velforberedt" (Kirsten).

Dette citat er udtryk for en rollefordeling mellem de studerende, som var genkendt af alle: Fordi nogle (oplægsholderne) var pålagt ansvaret for at gennemgå pensum, var resten af holdet i realiteten fritaget. Det var således tydeligt, at der gjaldt meget forskellige deskriptive normer for forberedelse af henholdsvis oplæg og ikke-oplæg. Mellem disse to positioner beskrev de studerende en tredje situation, nemlig arbejdet i læsegruppen forud for timerne.

"Det kan ske for alle [ikke at være forberedt] [...] hvis det er en fra min læsegruppe så spørger jeg selvfølgelig til [...] hvad er grunden?" (Arthur). 
De studerende forventede også, at medlemmerne af læsegruppen som udgangspunkt var forberedt til læsegruppemøderne forud for timerne. I modsætning til oplæggene kunne det dog undskyldes ikke at være forberedt.

I Figur 1 har vi forsøgt at rangere de deskriptive normer på et kontinuum fra acceptabel adfærd til uacceptabel adfærd. Øverst ses normerne for deltagelse. Nederst ses normerne for forberedelse. Nogle normers indbyrdes placering fremgik klart af datamaterialet. For eksempel syntes de studerende at være meget enige om, at det var helt uacceptabelt at være uforberedt til et oplæg, mens der var stor tolerance i forhold til medstuderende, der ikke var forberedt, forudsat at de ikke forstyrrede. Modsat var det vanskeligere at fastslå det indbyrdes forhold mellem fx irrelevante spørgsmål og forkerte svar. Figuren bør derfor opfattes som foreløbig og vil efter vores vurdering med fordel kunne undersøges nærmere.

Figur 1. Deskriptive normer for deltagelse i og forberedelse forud for holdtimen

$\begin{array}{lll}\begin{array}{l}\text { Sige noget, der opfattes } \\ \text { som en god pointe }\end{array} & \begin{array}{l}\text { Sige noget, der er } \\ \text { åbenlyst (rigtigt) }\end{array} & \begin{array}{l}\text { Sige noget, der ikke er rele- } \\ \text { vant for eksamen/ faget }\end{array}\end{array}$

Sige noget, der

Ikke at deltage (forudsat man ikke forstyrrer) viser sig at være

Acceptabelt forkert Uacceptabelt

Ikke at være forberedt til en time
Ikke at være forberedt til et læsegruppemøde
Ikke at være forberedt, når man har oplæg

\section{Sammenligning af påbudte og deskriptive normer}

Gennem analysen af de studerendes udsagn viste der sig en ikke ubetydelig forskel mellem de implicitte, påbudte normer og de deskriptive normer, som ofte afslørede sig gennem de studerendes faktiske handlinger. Fx var der en almindelig forståelse af, at man som studerende bør være forberedt til timen, og samtidig var der en meget vid tolerance over for medstuderende, som ikke var forberedte.

I nogle tilfælde lod det endda til, at de studerende var meget bevidste om den manglende sammenhæng mellem hvad, man forventedes at gøre (eller hvad man forventede andre gjorde), og ens egne handlinger:

"Ja, vi snakkede faktisk lige, da vi stod ude [på gangen]. Så var der en der sagde sådan: 'Ja, jeg føler mig helt dum. Jeg sidder der og vil gerne have at folk deltager, og jeg gør det jo ikke selv'." (Margrethe).

Dette citat er interessant fordi det viser en bevidsthed blandt de studerende om konflikten mellem de forskellige normer. Det var dog lige så bemærkelsesværdigt, at denne diskrepans mellem påbudte normer og faktisk handling sjældent gav anledning til at ændre holdning eller adfærd hos de interviewede studerende. 
Tabel 1. Sammenligning mellem påbudte og deskriptive normer

\begin{tabular}{|l|l|l|}
\hline \multicolumn{1}{|c|}{ Peltagelse } & $\begin{array}{l}|c| \\
\text { Der er ingen dumme spørgsmål } \\
\text { Alle er velkomne til at deltage i diskussi- } \\
\text { onen }\end{array}$ & $\begin{array}{l}\text { Forkerte svar er spild af tid } \\
\text { Kun (eksamens-) relevante spørgsmål er } \\
\text { velkomne }\end{array}$ \\
\hline Forberedelse & Man bør være forberedt & $\begin{array}{l}\text { Man har ret til ikke at være forberedt } \\
\text { (med mindre man har oplæg) }\end{array}$ \\
\hline
\end{tabular}

Tabel 1 opsummerer forskellene mellem de to typer normer. Den viser også det modsætningsforhold, der kan være mellem disse normer: At der ikke er dumme spørgsmål, men at forkerte svar er spild af tid; at alle i princippet er velkomne til at deltage i diskussionen, men at kun eksamensrelevante spørgsmål er legitime; at man bør være forberedt, men at man alligevel har ret til ikke at være det.

\section{Diskussion}

Det lader til, at der blandt denne gruppe studerende var klare normer, og at disse normer havde en adfærdsregulerende virkning. Det lader ydermere til, at disse normer resulterede i et meget begrænset handlingsrum, det vil sige, det var helt acceptabelt at holde sig helt uden for den fælles diskussion. Oversigtsartiklen af Rocca (2010) vidner om en tavshedens lov blandt universitetsstuderende. En tilbageholdenhed som nogle gange tolkes som, at studerende er dovne eller ikke gider deltage. Vores studier peger på en anden forklaring: De studerende er meget optagede af, hvad de andre studerende tænker om dem. Ingen vil opfattes som 'gymnasieagtig', bedrevidende eller dum. For de studerende betyder det, at handlingsrummet for at deltage i undervisningen bliver meget begrænset. De færreste bryder sig om at sige noget, der opfattes som selvfølgeligt, irrelevant eller som viser sig at være forkert. Derfor er det at tie stille og trække sig fra diskussionen den mest sikre - og i medstuderendes øjne helt accepterede - strategi. Sanktionerne ved normbrud er andre studerendes misbilligelse, der kommer til udtryk i uudtalte sociale sanktioner som $\mathrm{fx}$ 'rynken på næsen' eller diskrete suk.

Det er ikke helt tydeligt, hvor de påbudte normer stammer fra. I nogle tilfælde er det meget tydeligt, at det er en institutionel norm, når fx Robert siger, at det har været et problem siden folkeskolen, at man skal deltage mere aktivt. Andre gange virker det som om, at normerne baserer sig på en fælles forståelse blandt de studerende af, hvad hensigtsmæssig adfærd er. Det væsentlige er imidlertid, at det er de interne normer de studerende imellem, som de studerende primært orienterer sig imod og handler efter.

På mange universiteter er der en stor frihed for de studerende og derfor også en forventning om, at de i høj grad tager ansvar for egen læring. Hvad, der efter vores mening er meget bemærkelsesværdigt, er, hvor forskelligt studerende tolker og forval- 
ter denne frihed og dette ansvar. Flere studerende anvendte udtrykket "at vi har jo ansvar for egen læring" men tit i en kontekst, hvor det handlede om, hvad de var fri for at gøre. Friheden til at deltage i en diskussion blev retten til ikke at deltage. Dette blev legitimeret af, at læring er de studerendes eget ansvar. Det vil sige, at ansvar for egen læring ikke betød, at man burde tage ansvar men derimod kun, at man selv blev mødt af konsekvensen af sin adfærd. Dette er et paradoks: At undlade at tage del i og ansvar for undervisningen blev retfærdiggjort med henvisning til netop begrebet ansvar for egen læring.

\section{Begrænsninger}

Der knytter sig særligt to begrænsninger til dette studie, og den første vedrører resultaternes eksterne validitet. Studiet er foretaget blandt førsteårs-, statskundskabsstuderende i faget Politisk Teori og enhver generalisering ud over denne særlige kontekst og studenterpopulation skal naturligvis foretages meget varsomt. Ved at beskrive konteksten så fyldigt, som pladsen tillader det, vil vi lade det være op til læseren at vurdere, om lignende forhold med sandsynlighed gør sig gældende i pågældendes egen kontekst (Miles and Huberman, 2005). Den anden begrænsning vedrører datamaterialet. Normer som begreb var ikke tematiseret (Kvale, 2002) eksplicit i dataindsamlingen og derfor heller ikke ekspliciteret i interviewguiden. Dette betyder, at nogle af interviewpersonernes beskrivelser af normer er forholdsvis 'tynde'. Disse forhold må naturligvis tages i betragtning, når resultaterne vurderes.

\section{Implikationer}

Det er efter vores opfattelse meget uheldigt, at nogle studerende øjensynligt vælger at fortolke ansvar for egen læring som retten til ikke at tage ansvar. Hvis ikke de studerende tager medansvar for og medejerskab til at få undervisningen til at lykkes, er det meget sandsynligt, at holdundervisningen ender med at blive en gentagelse af forelæsningen, bare dyrere i drift og med mindre kyndige forelæsere. Vi tvivler på, at dette var meningen med at indføre holdundervisningen. Spørgsmålet er, hvad der kan gøres for at ændre situationen i de uddannelsesforløb, hvor de studerende vælger at være meget tilbageholdende i undervisningssammenhænge.

For det første må vi indse, at den kultur og de normer, som gør sig gældende blandt de studerende, ikke kommer ud af ingenting. Uddannelsesinstitutionen og underviserne er med til at skabe og vedligeholde normer, om ikke andet så ved at forbigå uheldige normer i tavshed. Dette gør os medansvarlige, om end ikke eneansvarlige. Som undervisere træffer vi valg om undervisningens organisering og eksamensform og -indhold. Hvis de studerende inden for denne ramme oplever, at det er rationelt ikke at forberede sig og at undlade at bidrage til undervisningen, så må vi genoverveje, om det er den rigtige undervisningsform, og om det er de rigtige krav, vi stiller til eksamen. Samtidig bliver vi nødt til at overveje, om vi i vores bestræbelser på at 
gøre det så godt som muligt for de studerende nogle gange kommer til at sende uheldige signaler. Det kan fx være, hvis vi for at nå igennem en stor mængde stof ender med at forelæse på holdtimerne og dermed giver indtryk af, at deltagelse er et forstyrrende element og forberedelse er unødvendig.

For det andet må vi være klar over, at det at påvirke veletablerede normer er en stor udfordring, som én underviser sjældent kan løfte alene. En særlig stor udfordring kan det være i de sammenhænge, hvor undervisningen varetages af unge eller nye undervisere. Det er en institutionel opgave at spørge de studerendes normer frem og konfrontere dem, hvis de er skadelige for aktiv deltagelse. Et universitetsstudie handler ikke kun om at mestre fagets teorier og metoder. Det handler også om at blive en del af et fagligt fællesskab med normer og værdier. En del af denne socialisering er, at den studerende tager ansvar og indgår som aktiv deltager i den faglige samtale.

Anna Bager er uddannet cand.scient.pol. fra Aarhus Universitet. Hun har siden 2007 været tilknyttet Center for Undervisning og Læring, Aarhus Universitet. Fra 1. februar 2013 har hun været ph.d.studerende samme sted. Hun forsker $i$ universitetsunderviseres opfattelse af undervisning og lxring $i$ relation til deres fag. Anna Bager har tillige arbejdet med Aarhus Universitets studiemiljøundersøgelser i både 2007 og 2011.

Kim Jesper Herrmann er cand.scient.pol. med en ph.d.-grad i Social Sciences and Business fra Aarhus Universitet med særligt fokus på samfundsfagenes didaktik. Han har siden 2007 været tilknyttet Center for Undervisning og Lxring, Aarhus Universitet, hvor han har varet fuldtidsansat siden 2009. Hans primære forskningsinteresse er organisering af holdundervisning og samspillet mellem studerende og undervisere. Desuden har han publiceret artikler om studiemiljø og studerendes oplevelser af og reaktioner på kooperativ læring.

\section{Litteratur}

Anderson, C. (2005). Enabling and Shaping Understanding through Tutorials, in Entwistle, Marton \& Säljö (eds.) The Experience of Learning. (2005): ch. 12, pp. 184-197.

Biggs, J. \& Tang, C. (2003). Teaching for Quality Learning at University, (second ed.). Maidenhead: Open University Press.

Cialdini, R. B., Reno, R. R. \& Kallgren, C. A. (1990). A Focus Theory of Normative Conduct: Recycling the Concept of Norms to Reduce Littering in Public Places, Journal of Personality and Social Psychology, 58(6), s. 1015-1026.

Herrmann K. J. (2013). Cooperative Learning in Higher Education: A study of the influence of cooperative learning on students' approaches to learning, ph.d.-afhandling, Aarhus Universitet (tilgængelig gennem Statsbiblioteket).

Hora, M. T. \& Anderson, C. (2012). Perceived norms for interactive teaching and their relationship to instructional decision-making: a mixed methods study, Higher Education, 64(4), pp. 573-592. 
Kvale, S. (2002). InterView (translated from InterViews: An Introduction to Qualitative Research Interviewing). København: Hans Reitzels Forlag.

Miles, M. \& Huberman, M. (2005). Qualitative data analysis: An expanded sourcebook. (2 ed.) Thousand Oaks: SAGE.

Rimal, R. N. \& Real, K. (2003). Understanding the Influence of Perceived Norms on Behaviours, Communication Theory, 13(2), s. 184-203.

Rocca, K. A. (2010). Student Participation in the College Classroom: An Extended Multidisciplinary Literature Review, Communication Education, 59(2), s. 185-213. 